\section{A Preliminary Study of the Food Habits of Natricine Snake, Amphiesma v. vibakari on Hegura-jima Island}

\author{
SEISHI KADOWAKI
}

\begin{abstract}
Amphiesma v. vibakari, the only snake species inhabiting Hegura-jima Island was collected. All snakes were forced to regurgitate stomach contents. Two snakes contained undigested earthworms. Another snake excreted a lump of mud which could be the remains of completely digested earthworms.
\end{abstract}

Key words: Amphiesma v. vibakari; Hegura-jima Island; Stomach contents; Earthworm

Hegura-jima Island $\left(37^{\circ} 50^{\prime} \mathrm{N}, 136^{\circ} 55^{\prime} \mathrm{E}\right)$ is a small island (the area about $2 \mathrm{~km}^{2}$ ) which is located $50 \mathrm{~km}$ north of Wajima on the Noto Peninsula, Ishikawa Prefecture, Japan. Only one natricine snake, Amphiesma v. vibakari occurs there (Ohno, 1969; Tokumoto, 1983; Ohgushi and Tokumoto, 1986). In the mainland of Japan, the diet of A.v. vibakari was reported to be anurans (Fukada, 1959; Moriguchi and Naitou, 1982). However, no anurans inhabit this island. This has lead to question of what are the food resources of $A . v$. vibakari on Hegura-jima Island. There were two hypotheses: 1) insects (e.g. Orthoptera) are the major prey items $(\mathrm{Ohno}, 1969)$ and 2) the lacertid lizard, Takydromus tachydromoides and earthworms are major ones (Sengoku, 1979). But no one has been able to document the food habits of $A$. v. vibakari on this island.

This paper is the first report of the food habits of $A$. v. vibakari on Hegura-jima Island. The snakes were collected during four days (18-19 May, 25-26 July) during the daytime in 1989. On 19 May, I surveyed mainly the western part of the island and on the other days the whole island. All individuals collected were forced to regurgitate their stomach contents. Snout-vent length (SVL) and tail length were measured to the nearest $\mathrm{mm}$.

Although active $A$. v. vibakari were not observed. 11 snakes (5 males and 6 females) hiding under stones or a board and two carcasses (1 male, 1 unknown sex) were collected (Table 1). One male (SVL $29.5 \mathrm{~cm}$ ) and one female (SVL $20.2 \mathrm{~cm}$ ) each contained a fragment of un-

Accepted 30 Nov. 1990
TABLE 1. Date, SVL and stomach contents of A. v. vibakari collected on Hegura-jima Island in 1989.

\begin{tabular}{clccc}
\hline Date & Sex & $\begin{array}{l}\text { SVL } \\
(\mathrm{cm})\end{array}$ & $\begin{array}{c}\text { Stomach } \\
\text { contents }\end{array}$ & Note \\
\hline 18 May & male & 36.7 & - & - \\
18 May & male & 34.6 & - & - \\
18 May & male & 28.7 & - & - \\
19 May & female 41.8 & - & gravid \\
19 May & male 21.6 & - & - \\
19 May & female 39.6 & - & gravid \\
19 May & female 39.8 & - & gravid \\
19 May & male & 35.1 & - & carcass \\
19 May & male & 29.5 & earthworm & - \\
19 May & female 29.2 & - & - \\
19 May & female 40.1 & - & - \\
19 May & - & - & - & carcass \\
26 July & female 20.2 & earthworm & - \\
\hline
\end{tabular}

digested earthworm (total length about $20 \mathrm{~mm}$ and $51 \mathrm{~mm}$, respectively). Another female (SVL $41.8 \mathrm{~cm}$ ) excreted a lump of feces. The analysis of the lump of feces showed no exoskeleton. It was inferred that a lump of mud in an earthworm eaten by $A$. v. vibakari was excreted without being digested. This was regarded as indirect evidence that $A$. v. vibakari fed on earthworms.

A. v. vibakari on Saru-shima is reported to consume the lacertid lizard, Takydromus tachydromoides (Aoki et al., 1979). On the other hand, $A$. v. vibakari artificially introduced to Miyake-jima consumed an earthworm and a hatchling skink, Eumeces okadae (Hasegawa, 1990). On Hegura-jima Island, the lacertid lizard, $T$. tachydromoides, which seems to be another potential prey of $A$. v. vibakari, occurs (Tokumoto, 1978; Nakamura, 1983). But so far we have not found the snake to prey on this lizard. This suggests that the food habits of $A$. v. vibakari on Hegura-jima Island are quite different from those on the Japanese mainland.

Acknowledgments.-I would like to thank Dr. R. Ohgushi, Dr. K. Nakamura, Mr. S. Sengoku and Ms. I. Hasegawa for critical reading of the manuscript. Thanks are also extended to Mr. M. Hasegawa for providing valuable references and to $\mathrm{Mr}$. K. Nishimura for his assistance in the field.

\section{Literature Cited}

Aoki, R., S. Takenaka and M. Hasegawa. 1979. Herpetofauna of Saru-shima, Tokyo Bay. In: Sarushima no Shizen (The nature of Saru-shima I.). p. 43-51. Kanko Shigen Hogo Zaidan, Tokyo. (in Japanese, with English abstract) 
FuKadA, H. 1959. Biological studies on the snakes. V. Food habits in the fields. Bull. Kyoto Gakugei Univ. Ser. B 14: 22-35.

Hasegawa, M. 1990. Ecological notes on the introduced population of the snake Amphiesma vibakari on Miyake-jima, the Izu Islands, Japan. Nat. Hist. Res. (1): 81-84.

Moriguchi, H. AND S. NaItou. 1982. Activities and food habits of Amphiesma vibakari (Boie) and Rhabdophis tigrinus (Boie). The Snake 14: 136-142. (in Japanese, with English abstract)

NAKAMURA, K. 1983. The records of herpetofauna on Hegura-jima. Nippon Herpetol. J. (25): 21-22. (in Japanese)

Oнgushi, R. AND H. Токuмото. 1986. Terrestrial fauna of Hegura-jima Island and Nanatsu-jima Islands, Noto Province. Bull. Japan Sea Res. Inst. Kanazawa Univ. (18): 17-18. (in Japanese)

OHNo, M. 1969. Notes on a snake, Natrix vibaraki,

\section{要旨 舳倉島のヒバカリの食性（予報）}

門脇 正史

1989年に 4 日間, 舳倉島に棲さ唯一のへビ類 であるヒバカリを採集した。すべての個体の胃 内容物を強制嘔吐法により検査した， 2 個体が 未消化のミミズの断片を含んでいた. また他 from Hegura Island, Ishikawa Prefecture, Japan. Jpn. J. Herpetol. 3(2/3): 17-18. (in Japanese, with English abstract)

SengoKu, S. 1979. Captive Amphiesma vibakari ate the lizard Takydromus tachydromoides. Nippon Herpetol. J. (13): 22. (in Japanese)

токчмото, Н. 1978. Gekko japonicus and Takydromus tachydromoides occur on Hegurajima. Nipponn Herpetol. J. (10): 11. (in Japanese)

Tокимото, H. 1983. The distribution records for the terrestrial and fresh water animals on Hegura-jima. Ishikawaken Koko Seibutsubukai Kaishi. (19): 2328. (in Japanese)

Department of Environmental Biology and Health Science, Graduate School of Natural Science and Technology, Kanazawa University, Kanazawa, Ishikawa, 920 JAPAN

の 1 個体は, 完全に消化したミミズの残りと思 われる一塊の泥を排泄した。

（920 石川県金沢市丸の内1-1 金沢大学大 学院自然科学研究科生命科学専攻環境生物学講 座) 